\title{
子どもたちの知のデータベース『総合百 科事典ポプラディア』をつくる
}

Editing The Encyclopedia Poplardia, a knowledge database for children

飯田 建 $^{1}$

IIDA Ken ${ }^{1}$

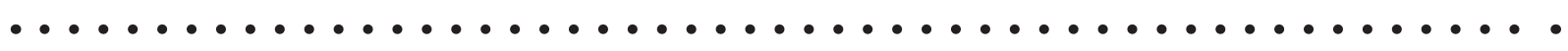

1 株式会社ポプラ社 ポプラディアネット局（テ160-8565 東京都新宿区大京町22-1） E-mail : info@poplardia.com

Tel : 03-3357-2256

1 POPLARDIANET, POPLAR PUBLISHING CO., LTD. (22-1 Daikyo-cho Shinjuku-ku, Tokyo 160-8565)

原稿受理 (2011-06-14)

情報管理５4(5), 243-253, doi: 10.1241/johokanri.54.243 (http://dx.doi.org/10.1241/johokanri.54.243)

著者抄録

小中学校の「調べ学習」や「総合的な学習の時間」において，子ども用百科事典は重要な役割を果たす。『総合百科事 典ポプラディア』全 12 巻は，9年前に刊行され，このたび改訂された日本で唯一の子ども用百科事典である。『ポプラディ ア』刊行は，子どもたちの「生きる力」，問題解決力を育てる教育のなかで百科事典を望む声が大きくなっていったこ とを背景としている。『ポプラディア』は五十音順の百科事典である。項目の選定や編集方針をはしじめとする製作の過 程について解説し，学校図書館における利用について紹介する。さらにデジタル化およびインターネット版「ポプラディ アネット」の開発，9年ぶりの改訂について記す。あわせて図書館とインターネットが教育の中で果たしている役割と 課題についても触れる。

キーワード

百科事典，知識，用語，編集，学校図書館，デジタル化，オンライン，データベース，インターネット，情報教育

1.はじめに

人類の英知をわかりやすく解説したデータベース， それが子ども用の百科事典である。子どもたちの学 習の中で，百科事典が大きな役割を果たすようになっ ている。

『総合百科事典ポプラディア』(以下『ポプラディア』 と記す）は，現代の日本で唯一の子ども用の百科事 典シリーズである。子どもたちが使っている百科事
典とはどのようなものなのか，その概略と製作の過 程，百科事典が必要な学習について解説する。あわ せて図書館とインターネットが子どもたちの学習の 中で果たす役割と課題についても述べたい。

2. 記録的なヒットとなった百科事典『ポ プラディア』シリーズ

シリーズ全体の出発点は，2002年3月に刊行された 
『ポプラディア』全12巻，小学生から中学生を対象と した五十音順の百科事典である。本書は2005年2月に 補遺版『総合百科事典ポプラディア プラス1 -2005 補遺一』を加え，13巻セットとなり，合計約50,000セッ トを販売した。日本全国の小中学校ほとんどすべて で利用されている。この『ポプラディア』を補い， 発展させるものとして，前述の補遺版をはじめ，い くつかのシリーズを刊行した。テーマ別の『ポプラ ディア情報館』（以下『情報館』と記す）シリーズ， インターネット版の「ポプラディアネット」，月刊誌 の『月刊ポプラディア』などである。これらについ ては，別章で解説する。

初版発行から9年を経た2011年1月，内容を一新し た『総合百科事典ポプラディア 新訂版』全12巻（以 下『新訂版』と記す)を刊行した(図1)。この『新訂版』 は，刊行時に10,000セットを超える予約を得，新年 度となった現在も好調に販売成績を伸ばしている。1 セット約10万円という百科事典が9年間も売れ続け， その新訂版が予約で10,000セット受注するというの は，出版界の常識では考えられない実績である。

ここで筆者と本シリーズとの関わりについて記し ておきたい。『ポプラディア』の着手時に筆者は編集 担当の一人であり，後述する大きな枠組みをつくる 過程のすべてに関わってきた。編集の作業が進む中

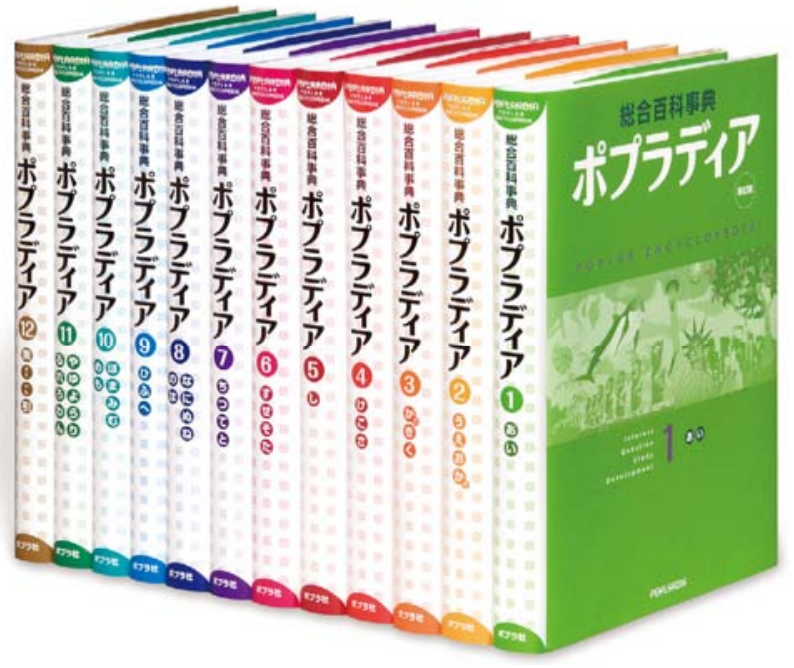

図1『総合百科事典ポプラディア 新訂版』（全12巻）

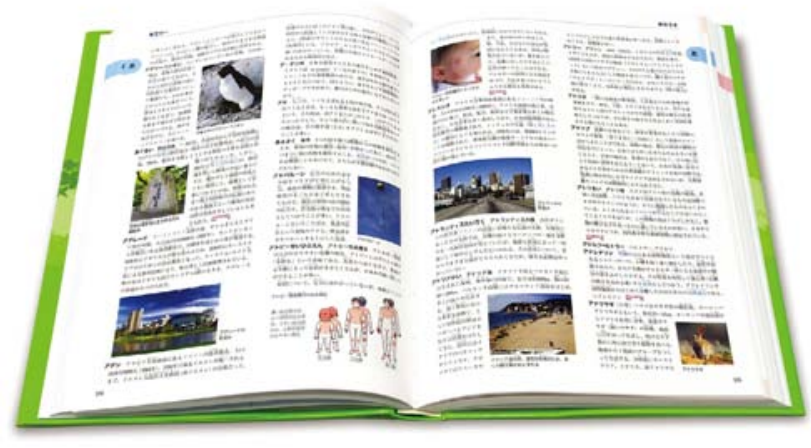

図2 『総合百科事典ポプラディア 新訂版』の本文

で異動し，初版刊行時は製作，宣伝の責任者を務め ていた。『ポプラディア』刊行後，本書をデジタル化 しさまざまに発展させることとなり，編集部に復帰 して，補遺版，月刊誌、『情報館』シリーズ，デジタ ル版などシリーズ全体の責任者となった。

編集が続いている子ども用百科事典の編集長とい う特異な立場であったがゆえに，日本全国の学校， 公共図書館，教育委員会などで指導的立場にある方々 に知己を得た。その結果，この数年，年間30〜40回 は，学校の授業で子どもたちに直接『ポプラディア』 の使い方を教えたり，先生方の研究会で講習などを 行ったりしている。また，書籍，雑誌，インターネッ トを統括する立場であったために，図書館関係者と 情報教育関係者，双方の方々と交遊いただいた。こ れら現場での経験も本稿の背景となっている。

\section{3. 子ども用百科事典を企画した背景}

百科事典というと，平凡社や小学館，ブリタ二カ などから刊行された大人用の大部のものを思い浮か べる人も多いだろう。日本には優れた百科事典がた くさんあり，かつて家庭などにも多く販売された。 子ども用においても玉川大学出版部刊のものなど， 多くの百科事典がつくられてきたが、『ポプラディア』 刊行以前は，しばらく新しいものがつくられていな かった。

大人用の百科事典は，急速にデジタル化が進み， 
身近なものとなっていった。パッケージソフトとし てCD-ROMやDVD-ROM版がつくられ，やがてイン ターネット版が開発された。電子辞書にも搭載され ていった。こうしたデジタル化の流れの中で，書籍 ではなされなかった情報の更新が行われたものが多 い。

子ども用の百科事典は，書籍でもデジタルでも新 しいものはつくられていなかった。だが，真に百科 事典を求めていたのは，子どもたちと学校だったの である。

子どもたちの学習は大きく変わりつつある。暗記 して知識を蓄積していく教育から，「生きる力」を身 につけるための教育へと変化してきている。ここで いう「生きる力」とは何か。もちろん学習の基礎と なるものは覚えるしかない。しかし，現代の社会を 生き抜いていくには，まだ一度も出会ったことのな いような問題に日々向き合っていかなければならず， 問題を解決する力の方がむしろ重要になる。その問 題解決の力を養うために，「調べ学習」や「総合的な 学習の時間」がある。

「調べ学習」も「総合的な学習の時間」も，子ど もたちが主体的に図書資料やインターネットなどを 使って調べる学習である。社会科や理科など教科の 単元の中で行われ，与えられたテーマを調べるのが 「調べ学習」であり，テーマを自ら探すところから始 めるのが「総合的な学習の時間」である。調べると いう学習活動の中でその第一歩となるもの，それが 百科事典なのだ。調べ学習が盛んになり，総合的な 学習の時間をどのように行っていくかが検討される 中で，百科事典を望む声が大きくなっていった。

こうした流れのなか『ポプラディア』は企画され， こうした学習に応えることができる唯一，最大の資 料であるがゆえに，これだけのヒットとなったので ある。

\section{4. 製作の過程}

\section{1 テーマ別，教科別か，五十音順か}

あるとき，小社の坂井宏先 (現在は社長) が，学 校図書館の指導的立場にある先生から「子ども用の 百科事典がない」という示唆を受けた。その一言か ら本プロジェクトはスタートした。

百科事典といっても，さまざまなタイプのものが ある。どのような百科事典をつくるのか，決めてい かなければならない。まず，規模と想定価格を決め た。単冊ではいかにも情報量が少ない。ある程度の 情報を網羅しようとすると，分冊とせざるを得ない。 子どもたちが取り扱いに困るような大きさにはでき ないので，大きさ，厚さもイメージし，パッケージ 全体としてはこれくらいの大きさであろう，そして それならば，価格としてはこの程度であろう，とい う大まかなことを決めた。

これと並行して悩んだのが，テーマ別，教科別に するか，五十音順にするかである。編集部は，テー マ別を支持する意見が当初多数を占めた。テーマ別 のほうが圧倒的につくりやすいからである。テーマ 別であれば，目次をつくり，論を積み上げていくこ とができる。章ごとに，見開きごとにつくっていく ことができる。用語を解説するうえでも，これは前 章で説明済み，として進めることができる。つまり 普通の本のつくり方の延長線上でつくることができ るのだ。五十音順となると，その項目単独で理解で きるよう原稿を整えなければならない。そして，見 開き内にあらゆるテーマ, ジャンルの用語が並ぶ。 つまり，すべての原稿ができてからではないと，レ イアウトすらできないということになる。百科事典 を初めてつくる編集部としては，これらの事態を恐 れた。

しかし結局は五十音順を選択することになった。 主な理由は2つある。1つは，調べ学習などで求めら れているのは，特定のキーワードに素早くたどり着 くことであろう，ということ。2つ目は子どもたちが 
探そうとするキーワードが，うまく特定の言葉でま とめられたテーマにおさまらないのではないかとい うことである。

「このキーワードはどの巻で調べればいいだろ う?」などということを考えさせるようでは使って もらえないのではないか，またそもそも，現在の社 会は複雑化しつつあり，テーマ別におさまりきらな い用語が増えているのではないか，と考えた。解説 が必要な用語を適切なテーマに分けて，網羅的に配 置することは大変困難なのだ。また，図書館の考え 方によるが，テーマ別にすると，それぞれのテーマ ごとの書架に分けて配架される可能性がある。この 場合，さらにキーワードにたどり着くことが困難に なる。こうして五十音順とすることを決めた。

\section{2 項目の選定}

次は項目の選定である。これは当時の教科書を調 べることから始めた。

小中学校の全学年，全教科，全出版社の教科書を 購入し，そこに掲載されている語のリストをつくつ ていったのである。これが選定基準の第一優先順位 となった。これに，数年分の小学生新聞，中学生新聞， 学年誌を加えていった。さらに，『現代用語の基礎知 識』（自由国民社刊）、『imidas』(集英社刊)，『知恵蔵』 （朝日新聞社刊）など当時の年度版の用語集数年分を 加えた。最後は一般向け百科事典との突き合わせで ある。このほか，図鑑など，ジャンルによっては別 の資料も突き合わせた。こうして緃軸に用語，横軸 にその語の掲載元をあらわした，膨大な語のリスト が出来上がった。これを頻度順に並び替えた。頻度 だけで語の軽重が決まるわけではない。用語をジャ ンルごとに分解し，各ジャンルの専門家とジャンル 内での語の過不足を精査した。

こうして広く拾い集めた語を絞り込んでいったの である。いくつに絞り込むかもまた悩みの種であつ た。語を解説するのに必要なボリュームを，特大，大， 中，小に分け，想定したページ数，行数の中で何項
目おさめられるかを計算した。

ジャンルごとに絞り込んでいく作業を依頼した專 門家，研究者にはそのままそのジャンルの指導をし ていただいた。また直接の執筆もお願いし，その他 多くの研究者，専門家もご紹介いただいた。こうし て100人以上の執筆者が一斉に原稿に着手した。

\section{3 編集の方針と実作業}

原稿執筆の方針として，正しいこと，わかりやす いことは当然のことであるが，読んで楽しいことを 心がけた。知る喜びが得られるよう，まるで物語を 読んでいるかのごとくわくわくするものを，という ことである。

一般の百科事典の多くは，記名原稿である。各項 目の解説は，執筆者のいわば小論文のようなもので あり，学説等は，執筆者の判断，責任に任される。 ゆえに執筆者の主義主張があり，項目間に整合性が なくても問題にはならない。数十巻にも及ぶものを つくり上げるうえではやむを得ないことであるとと もに，一般の用をなすものとしては当然のことであ る。

しかし本書は，子どもたちが読むものである。で きるかぎり客観的で，できるかぎり定説を取り上げ， 項目間で表記のゆれや，立場の違う解説となること は避けたい。そこで本書では，基本的に無記名とし， 編集部の責任でこれらの調整を図ることにした。

「正しく」と「わかりやすく」は必ずしも容易に両 立するものではない。「わかりやすく」噛み砕いてい くと，科学として「あいまい」な表現となり，「誤解」 を生むことにもなりかねない。項目解説中に別の用 語が登場するのは当然のことであり，これらを無制 限に説明なく使っていけば，執筆は容易になるが， 読者の理解を遠ざけることとなる。

こうしたせめぎ合いが，すべての項目で起こった。 專門家の書いた原稿を編集部でリライトし，それを また専門家に確認してもらう。お互いが納得できる 妥協点を繰り返しのやり取りの中で見出していくし 
かないのである。

原稿の執筆を行いながら，写真の収集やイラスト， 図表類も作成していった。各項目の必要に応じて作 成したのであるが，現実には紙幅の限界もあり，ま た見開きごとのビジュアル的要素にボリュームの差 がありすぎるのも好ましくない。しかしすべてを用 意し，レイアウトを開始してみないとわからなかっ たことも多い。せっかく用意しながらやむを得ず削 除したものや，逆に追加したものも多数ある。

編集作業を進めながらも，新たな発見による学説 の変更や社会の変化などには，当然対応しなければ ならない。こうした変化，進化に対応して，項目の 追加と削除，原稿の修正が校了時ぎりぎりまで続け られた。しかし，「旧石器遺跡捏造事件」や「アメリ 力同時多発テ口事件」は，想定外に広範囲かつ大幅 な内容の見直しを迫る容易ならざる事態であった。

なお，『ポプラディア』シリーズは基本的に，現代 日本語を現代仮名遣いで書き表している。漢字は， 固有名詞や専門用語などの一部例外を除き，常用漢 字を使っている。また，小学生4年生以上で学習する 漢字にはふりがなをふった。

\section{5. どのように使われているのか ?}

『ポプラディア』が一番多く使われている場は小中 学校の図書館である。社会科など教科の学習の中で， 前述の「調べ学習」が多く行われている。教科書に「図 書館で調べてみよう」とか「インターネットで調べ てみよう」などの指示があるものもあれば，先生方 独自の判断で行われることもある。

「総合的な学習の時間」は，子どもたち自身が自ら テーマを決め，自ら調べ，自らまとめ，発表する学 習である。1年間かけて行われることが多い。『ポプ ラディア』はすべてのジャンルをカバーしているの で，調べる第一歩としてはとても有効な資料として 使われている。

図書館の利用指導の中で，知りたい情報にいかに
たどり着くかは，大変重要な基礎的スキルであるが， 残念ながら十分指導が行き届いているとは言えな い。図書館の中で「調べましょう」と言われて，ど の本をどう見てよいかわからず，書架の前をうろう ろするだけで1時間が終わってしまったというのは珍 しいことではない。分類を理解し，配架のルールを 学び，書名・著者名・件名といった目録の検索，目 次や索引，奥付の理解などの基本的スキルは，繰り 返し行わないと身につかないものである。『ポプラ ディア』は，一番便利で役立つ資料であるとともに， こうした学習を行っていくうえの第一歩として活用 されている。

一度も手に取ったことのない子どもにとって，『ポ プラディア』は厚くて重くて，なんだか難しそうな 本に見える。しかし，一度でも手に取った子どもに とっては，何か調べるときにまず手を伸ばす大切な ものとなる。『新訂版』で約25,000項目あり，索引巻 を利用すれば50,000語を検索できる（図3）。「調べた らわかった」という喜びが得られる本なのだ。この 成功体験が継続的な調べ学習につながっていく。

筆者は『ポプラディア』を通読した小学生2人に出 会った。最初の1人との出会いは強烈だったのでよく

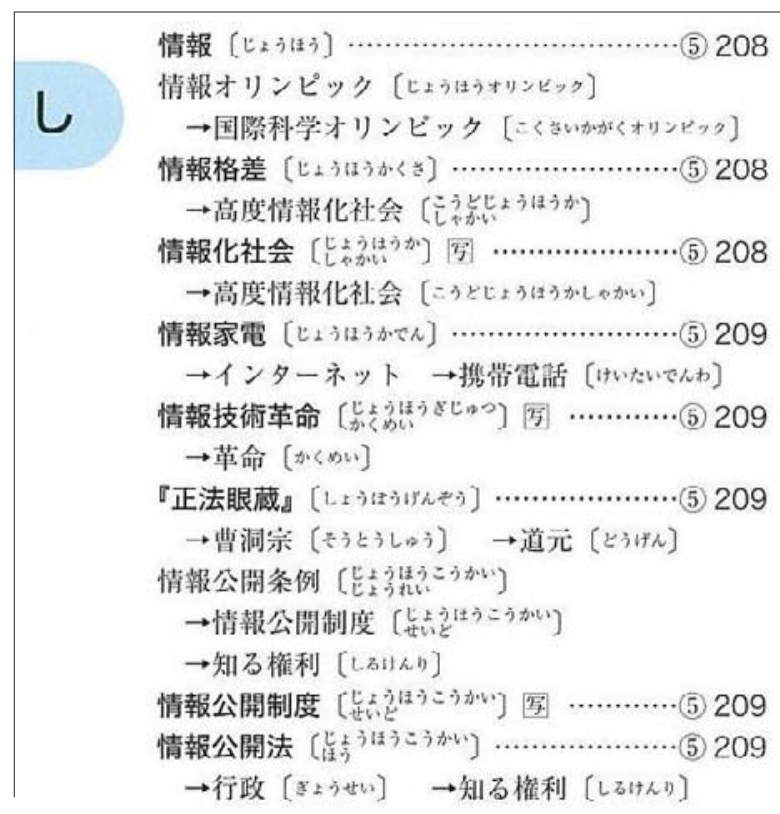

図3『新訂版』の索引 
覚えている。『ポプラディア』の利用方法を指導する 授業中，よく発言してくれた子どもなのだが，会話 が噛み合わなくて，もどかしさを感じた。授業のあ とわかったのだが，彼は私の授業を受けるまで百科 事典の本来の利用方法を理解していなかった。彼は 調べることなく，1巻の1行目から最終巻の最後の行 までを読み通していたのである。彼にとって『ポプ ラディア』は，知らないことが書いてあり，しかも それがすべて「本当のこと」であるという強烈なエ ンターテインメントの書だったのだ。2人目も同じよ うな子どもであった。

児童文学評論家の赤木かん子氏は講演の中で，子 どもたちの読書傾向を「空想系」と「リアル系」に 分けて考えている，と語る。「空想系」の子どもは，「も のがたり」が好き。「ものがたり」の中で想像をめぐ らし楽しむことができる。「リアル系」の子どもは「も のがたり」を読むのが好きではない。ただし「本当 のことが書かれている本」を読むのは好きなのだと いう。

世の中で「本嫌い」と思われている子どものうち， かなり多くがこの「リアル系」ではないだろうか。 読書指導を通じて「ものがたり」の本としか出会つ ていないがゆえに，「本が嫌い」と思われている子ど もが少なからず存在するのである。

筆者が授業をしたクラスで，多くの先生方から，「あ
の子があんなに楽しそうに発言するのは初めてみた」 などと言われた。読書の時間，いつもつまらなそう にしていた子や，図書館嫌いと思われていた子ども である。彼らの多くが「本当のことが書かれている本」 に出会ったとき一変する。赤木かん子氏によると、『ポ プラディア』は，「本当のことが書かれている本の王 様」なのである。

\section{6.『月刊ポプラディア』の発行とデジタル 化}

最初の『ポプラディア』刊行の直後から，デジタ ル化に着手し（表1），それとほぼ同時に『月刊ポプ ラディア』（図4）を刊行した。

『月刊ポプラディア』は，総合学習応援雑誌を謳 い，毎号1テーマを詳細に解説するものであった。同 時に補遺の役目も果たし，毎号新規項目を掲載した。 百科事典の必要性をアピールし，新しい情報を届け るという役割を担うものであったが，『新訂版』の刊 行を機にその役目を果たしたとして，2011年4月号を もって休刊とした。

デジタル化はまず2004年12月に『総合百科事典デ ジタルポプラディア2005』として，いったんDVDROMのパッケージソフトで刊行した。その翌年，『総 合百科事典デジタルポプラディア プラス1 2006』

表1『ポプラディア』シリーズの歩み

\begin{tabular}{|r|l|}
\hline 1998年12月 & 文部科学省が学習指導要領を告示。『ポプラディア』の企画を本格的にスタートさせる \\
\hline 2002年 3月 & 『総合百科事典ポプラディア』(全12巻)刊行 \\
& 同書が2002年度の第4回学校図書館出版大賞を受賞する \\
\hline 2003年 9月 & 『月刊ポプラディア』創刊 \\
\hline 2004年12月 & 『総合百科事典デジタルポプラディア2005』発売 \\
\hline 2005年 2月 & 『総合百科事典ポプラディア プラス1 -2005補遺-』刊行 \\
『ポプラディア情報館』シリーズ刊行開始 \\
4月 & $\begin{array}{l}\text { 『ポプラディア学習帳』シリーズ発売開始〈セイカ(現在のサンスター文具)より〉 } \\
\text { 11月 }\end{array}$ 『総合百科事典デジタルポプラディア プラス1 2006』発売 \\
\hline 2006年11月 & 『総合百科事典デジタルポプラディア プラス2 VOICE発売 \\
& インターネット版百科事典「ポプラディアネット」サービス開始 \\
\hline 2011年 1月 & 『総合百科事典ポプラディア 新訂版』(全12巻) 発売 \\
& 『ポプラディア情報館』シリーズ7巻を同時発売, 全50巻となる \\
\hline
\end{tabular}




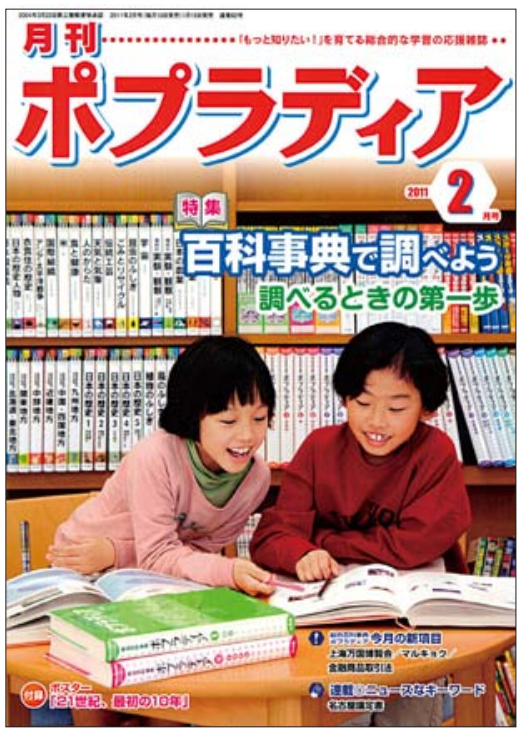

図4『月刊ポプラディア』2011年2月号

を，さらに翌々年『総合百科事典デジタルポプラディ ア プラス2 VOICE』を発売した。いずれもメディ アはDVD-ROMであったが，毎月インターネットで補 遺情報をダウンロードできるようにした。最後の版 の『VOICE』は，本やノート，鉛筆から手を離さなく ても操作できるようにとの願いから音声認識機能を 搭載した。音声認識は急速に進化している分野だと 思うが，筆者はいまだにこれが日本で最も使いやす い音声認識ソフトであると信じている。

この間，パッケージソフトからインターネット配 信型への転換も進め，2006年11月，インターネット 版の「ポプラディアネット」のサービスを開始した。 これについては次章で述べる。

テーマ別の『情報館』シリーズは，2005年3月から
刊行を開始し，2011年1月で全50巻となった。五十音 順では十分学習しきれない体系だった情報をテーマ ごとにまとめたものであり，より詳しい学習ができ るように配慮されている。全50巻で，子どもたちの 学習に必要な範囲をほぼ網羅するものとなっている (図5)。

こうして書籍，雑誌，インターネットと，子ども たちが必要とするすべてのメディアで百科事典を活 用してもらえる態勢が整った。

なおこの間，無料で「ポプラディアネット」の一 部を利用できる「ナビポ」(http://navipo.jp/)，その 携帯版「モブポ」(http://mobpo.jp/) のサービスも 開始した。サンスター文具から「ポプラディア学習帳」 シリーズも発売されるなど，「ポプラディア」は学習 ブランドとして大きく育っていった。

7.インターネット版開発の思想

インターネットで配信している「ポプラディアネッ 卜」（図6）は，『新訂版』、『情報館』シリーズと並ぶ， 3つ目の大きな柱の1つである。同じテキストをもと にスタートしているが，インターネットでなければ できないことを追求している。

デジタル版の特性として検索性に優れているのは 言うまでもない。ポプラディア全巻の情報を瞬時に 全文検索できるのは，紙ではあり得ない感覚である。 音声，動画といった紙では表現し得ないものも数多 く収載している。五十音順の百科事典は受け継いで

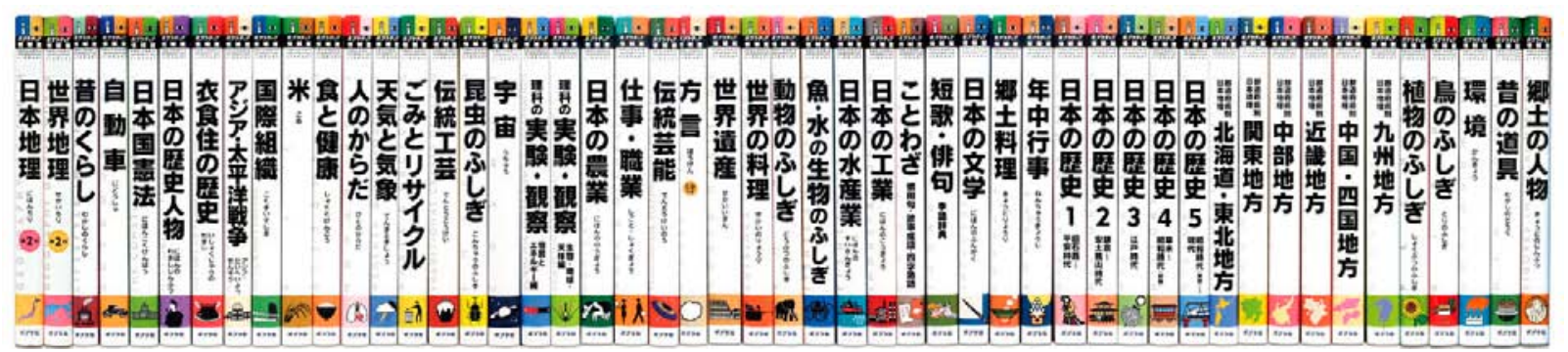

図5『ポプラディア情報館』シリーズ（全50巻） 


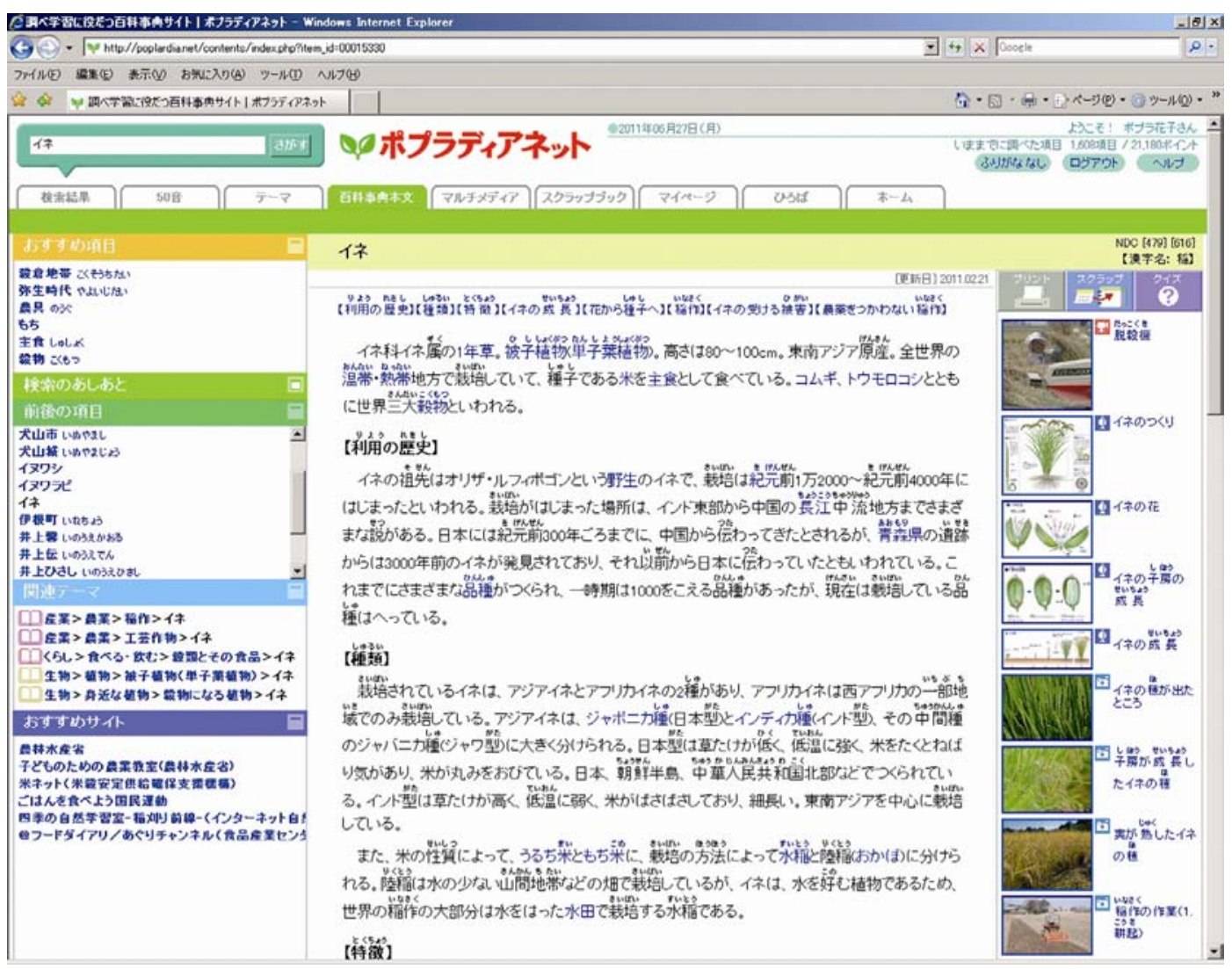

図6「ポプラディアネット」の項目「イネ」

いるが，多くのリンク機能を活用することによって 学習の発展性に優れたものとした。新しい項目を追 加したり，統計情報など新しい情報を追加修正した りすることも当然行っている。ふりがなの有無を選 ぶボタンも用意している。

学習の発展性についてもう少し詳しく記したい。 書籍で「イネ」がテーマとなった本があるとする。 この本には，植物としてのイネのことも，農業のこ とも，栽培の歴史のことも，食べ物としての文化の こともさまざま書かれている。「生物」「産業」「歴史」 「食」は図書館の中で異なる分野として扱われる。図 書館で購入された本は，登録され，装備がなされ， 配架される。このとき，どの分野に配するかは図書 館員，司書が決める。筆者自身，自分が担当した本 が思わ妢類を付与されて驚くことがある。「日本十 進分類法」という大きな基準はあるものの，それを もとに決めているのは最終的には個人なのだ。図書
館は，同じ本は複数購入したとしても，それぞれに 別の分類を与え，複数の場所に配架することは基本 的にない。子どもが図書館で有効な本に出会えない のは，この配架のルールを理解していないため，と いうことも多いのだ。

「ポプラディアネット」では，複数の「関連テーマ」 を表示して，五十音順の百科事典をテーマ別の資料 のように使うこともできるよう配慮している (図7)。 「イネ」の項目からは，稲作，工芸作物，穀類，被子 植物，穀物へと案内される。各項目には，図書館の 本も活用してほしいという願いをこめて「日本十進 分類」(NDC) も付与している。「イネ」に対しては， 479 (被子植物) と616（食用作物）のように複数の 分類を付与している。

「ポプラディアネット」は学校や公共図書館，家庭 と，さまざまな場で活用されている。当初はIDとパ スワードでユーザー管理する形態のみであったが，IP 


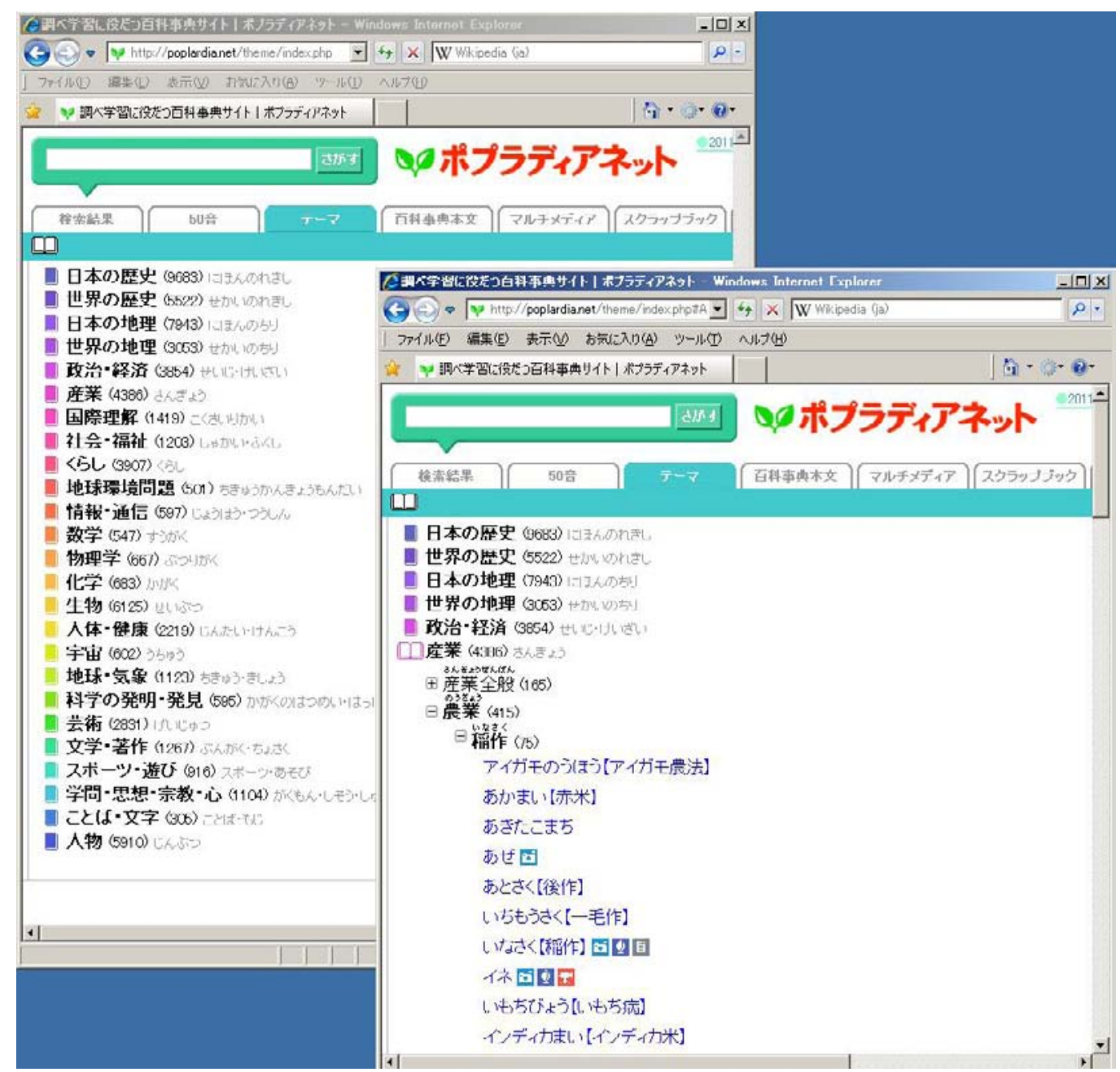

「ポプラディアネット」の各項目は，25の大テーマに分類されている。各テーマの後ろに（ )であらわさ れている数は，そのテーマに含まれている項目の数。25の大テーマは，さらに中・小テーマに分類されて いる。小テーマは1,400以上に細分化される。

図7「ポプラディアネット」のテーマ別分類

アドレスで管理する仕組みも用意した。千葉県柏市 などのように，市教育委員会として一括採用する自 治体も増えている。柏市の場合，市内61の小中学校， 6,000台のパソコンから自由に使えるようになってお り，大変有効に活用されている。

ある大手の中学受験進学塾では，数万人の塾生全 員が家庭学習で「ポプラディアネット」を利用して いる。この熟ではカリキュラムの理解度をはかるテ ストの結果をネット経由で閲覧できるシステムを構 築していて，問題解説の中の重要語には「ポプラディ アネット」へのリンクを張つているのだ。
このように，オンラインデータベースとしての「ポ プラディアネット」の利用は拡大している。

\section{9年を経て新訂版に}

『ポプラディア』シリーズ全体を通して蓄積してき たものをすべて活かし，2011年1月，『新訂版』を刊 行した。旧版の発行から9年が経過し，もう補遺版 では内容の修正が追いつかなくなつていた。市町村 合併，省庁再編や独立行政法人化などの行政改革は わかりやすい例だが，日本も世界も社会が大きく変 
化し，また科学の分野でも，「はやぶさ」など新しい 研究成果が次々に生み出されている。こうしたこと に対応して全項目を見直した。その結果，項目数は， 約23,000項目から約 25,000 項目に。総ページ数も，約 3,000ページから約3,500ページにと増加した。またこ の『新訂版』では，『情報館』シリーズに詳しい解説 のある項目はそのページを掲載し，参照できるよう 工夫した。50巻にも及ぶ専門的書籍への対応づけは， 百科事典として世界初の試みである。

前述のように，9年間にわたつて50,000セットも販 売してきたシリーズを改訂して，10,000セットも予 約販売できたということは，それだけ活用され，な おかつ新しい情報に入れ替える必要があるとの認識 がなされているという証左である。すでに，次の補 遺版，三訂版についてのぶ質問も受けており，今後 の展開については十分検討して進めていきたい。

\section{9. 紙もネット版も，図書館もインターネッ 卜も}

ここまで述べてきたように、『ポプラディア』シリー ズには、「紙」も「ネット」もある。とかく，紙かネッ トか，という議論があるが，こと，子どもたちが学 ぶ「知のデータベース」に関しては，この議論はナ ンセンスだと考えている。「紙」も「ネット」も，ど ちらも必要なのだ。そう信じてどちらもつくってき た。

紙を展開する大事な場としての図書館とインター ネットを対比させて考えてみたい。

図書館は，人類の英知を集積し，それを体系づけ， 手を伸ばせばいつでも利用できるように配架した場 である。われわれは図書館に一歩入った途端，人類 の英知を一望することができる。紙，印刷という技 術，本というメディアは，とても扱いやすく，便利で， 図書館という空間の中で知のデータベースを構築し てきた。

インターネットも人類の英知を集めた第二の場と
なっている。インターネットの登場によって，子ど もたちが利用できる知の引き出しが増えたのであ る。ただし，インターネットはとても便利なもので あるが，玉石混交であり，体系づけられていない。 ここが図書館との大きな違いになっている。

図書館には，編集者，司書という専門家のフィル ターを経た資料が集められており，それは利用者に 対する大きな保証になっている。大人はインターネッ トと図書館の利用についてのこの基本的な違いを感 覚的に理解しているが，子どもたちがこれを理解す るのは大变難しい。

また，多くの場合，インターネットで「調べる」 ことは検索エンジンに委ねられるが，子どもたちは 無批判にその検索結果を受け入れてしまう。検索結 果の最初の1行目から順にページを開いていき，調べ たいことが見つかるとプリントアウトして，学習が 終わった気になってしまうのだ。そこに比較や検証 はない。

検索エンジンではピンポイントで，容易に知りた いことにたどり着けることが多いが，その背景とな る全体像を見渡すことにはつながらない。図書館な ら，書架の前に立つただけで，その世界を補足する 資料のさまざまなタイトルに目がいく。書架の間を さまようだけで，情報の選別，絞り込む作業が無意 識に行われている。検索エンジンはこの過程を飛ば し，本でいえばページの該当の行に一気に連れていっ てくれる。しかも近年，検索エンジンはますます進 化している。検索のゆらぎに対応し，推測して導い てくれる。

ネット検索の優位性や情報提供のスピードに，お そらく紙はもう二度と追いつくことができない。ま た紙にはコストとスペースが必要となる。個人の選 択肢としてこの問題は大きい。

子どもたちにとって，紙とネット版，図書館とイ ンターネットは，比較し，どちらかを選ぶものでは ない。どちらにも良いところがあり，苦手なところ がある。子どもたちには，図書館もインターネット 
も正しく利用できるようになってもらいたい。それ らの特性を理解し，必要なときに，より良いものを 選べるようになればいいのだ。

新しく校舎が建築される場合，学校図書館が，そ の校舎の中心，どの教室からも一番行きやすい場所 に配置されることが多くなっている。また，図書館 の隣にコンピューター室が置かれ，2つ合わせて学習 センターとして機能するようになっていることも多 い。一番望ましいのは，この2つの境がなく，鍵もか かっておらず，いつでも子どもたちが自由に利用で きる環境にあることだ。子どもたちの情報収集の場 は，いつでも開かれていてほしいと考えている。

\section{0.おわりに}

『ポプラディア』シリーズは，家庭でも図書館でも， 冊子でもインターネットでも活用してもらえる日本 語の唯一の子ども用百科事典である。今これに代わ るものはない。大げさに思われるかもしれないが， このシリーズをより多く活用してもらうことは，子 どもたちの学習をより豊かにしていくこと，日本の 未来につながることだと考えている。子どもたちの 学習を支えるものとして，さらに発展させていかね ばならない。

次回は，さらに「ポプラディアネット」の先進的 な活用事例を現場の担当者とともに紹介する。あわ せてオンラインデータベースの有効活用も論じたい。

\section{Author Abstract}

Encyclopedia for children plays an essential role in the "learning by consulting" curriculum and the "integrated study period" in elementary and junior high schools. The Encyclopedia Poplardia, first published in March 2002 in 12 volumes and recently revised, is the only encyclopedia in Japan designed for children. The publication originates from the needs for such an encyclopedia as is targeted at children, which grew as the school education aimed at nurturing the fortitude to live and the ability to solve problems. The Poplardia employs the longer/shorter entry types, with its content listed in the order of the 50-character kana syllabary. This article looks at how the Poplardia is edited, including how subjects are selected and what the editing policy is, and how it is used in school libraries. It covers the launch of new online service "Poplardia Net" and the first revision in 9 years. It also refers to the roles libraries and the internet play in teaching and learning and some of the challenges to be dealt with.

\section{Key words}

encyclopedia, knowledge, word, editing, school library, digitization, online, database, internet, information education 